\title{
Considerații etice privind managementul Covid-19 la pacientul vârstnic spitalizat - Studiu de caz ${ }^{1}$
}

\author{
Maria-Elena COCUZ', 2, *, Iuliu-Gabriel COCUZ ${ }^{3,4}$ \\ 1 Universitatea Transilvania din Brașov, \\ maria.cocuz@unitbv.ro \\ 2 Spitalul Clinic de Boli Infecțioase Brașov \\ 3 Universitatea de Medicină, Farmacie, Științe și \\ Technologie „George Emil Palade” Târgu-Mures \\ 4 Spitalul Clinic Județean Mureș \\ * Correspondence: maria.cocuz@unitbv.ro
}

Citation: Cocuz, M.E. \& Cocuz, I.G. (2021). Considerații etice privind managementul Covid-19 la pacientul vârstnic spitalizat - Studiu de caz. Revista Etică și Deontologie, (1)1, 74-81,

https://doi.org/10.52744/RED.2021.01.09

Publisher's Note: RED stays neutral with regard to jurisdictional claims in published maps and institutional

\section{(c) (i)}

Copyright: (C) 2021 by the authors. Submitted for possible open access publication under the terms and conditions of the Creative Commons Attribution (CC BY) license

(https://creativecommons.org/ licenses/by/4.0/).
Rezumat: Infecția cu SARS-Cov-2, denumită Covid-19, cu evoluție declarată pandemică de OMS în martie 2020, determină variate forme de boală, gravitatea crescând odată cu vârsta și cu prezența de comorbidități. Pacientul vârstnic cu Covid-19 necesită frecvent internare în spital pentru tratament și supraveghere medicală. Lucrarea de față prezintă un studiu retrospectiv efectuat pe cazuistica Spitalului Clinic de Boli Infecțioase din Brașov în perioada 01.03.2021-31.03.2021, axat pe evidențierea unor aspecte etice legate de particularitățile îngrijire medicală ale pacienților cu vârsta peste 65 ani. În perioada menționată proporția bolnavilor vârstnici a fost de $51,48 \% \%$ din totalul internărilor, mare parte dintre aceștia prezentând forme medio-severe și severe de boală și având asociate multiple comorbidități. În acest context asistența medicală acordată pacientului vârstnic spitalizat cu Covid-19 trebuie sa fie nediscriminatorie și să cuprindă aplicarea echitabilă a tratamentul specific, intervențiile în caz de urgență medicală și accesul la servicii de specialitate pentru bolile cronice asociate în cazul decompensării acestora.

Cuvinte cheie: managementul Covid-19, vârstnic, etică

\footnotetext{
${ }^{1}$ Articol prezentat în cadrul Conferinței Internaționale Valorile Etice în Societatea Actuală - VESA 2021 (3-5 iunie).
} 


\section{Introducere}

COVID-19 (Coronavirus disease 2019), boală virală cauzată de SARS-CoV-2 (severe acute respiratory syndrome coronavirus 2), a fost raportată la Organizația Mondială a Sănătății (OMS) la 31 decembrie 2019, noul coronavirus fiind identificat ca fiind cauza unui focar de cazuri de pneumonie in WUHAN, China la sfârșitul anului 2019. În 30 ianuarie 2020 OMS apreciază COVID-19 ca reprezentând o urgență globală de sănătate iar în 11 martie 2020 infecția produsă de noul coronavirus SARS-CoV-2 este declarată pandemie globală, datorită răspîndirii rapide în întreaga lume. În aprilie 2020 Centrul de Prevenire și Control al Bolilor (CDC) din Atlanta, SUA, apreciază că „această situație ar putea duce la un număr mare de pacienți care să necesite îngrijire medicală concomitentă, cu supraîncărcarea sistemelor de sănătate, rate crescute de spitalizare și decese". (Cennimo, 2019; WHO, 2020a; WHO, 2020b; Q\&A COVID-19, 2021; WHO, 2020c).

La data de 12 iulie 2021 se raportează pe glob 187.511 .690 cazuri de COVID-19 și 4.063.474 decese. În România s-a înregistrat până la 11 iulie 2021 un număr de 1.081.236 de cazuri confirmate de infecție cu SARS-CoV-2, din care 34.217 decese (INS, 2021a). Până la data de 4 iulie $86,1 \%$ din decese s-au înregistrat la pacienți cu vârsta de peste 60 de ani iar $94,7 \%$ dintre persoanele decedate aveau cel puțin încă o boală asociata (INS, 2021b).

Conform datelor din literatura de specialitate severitatea COVID-19 variază de la forme asimptomatice și ușoare la forme critice. Printre factorii de risc pentru forma severă/critică de COVID-19 și pentru risc crescut de deces se menționează vârsta (peste 80\% din decese prin COVID-19 apar la persoane cu vârsta peste 65 de ani) și bolile cronice de fond pe care le prezintă pacientul: diabet zaharat, cancere, boli cardiace, boala renală cronică, boli cerebro-vasculare, obezitatea, boli respiratorii cronice, boli imunosupresoare etc. (Q\&A COVID-19, 2021; Guan et al., 2020; Onder et al., 2020; Britannica, 2021; Interim Clinical Guidance, 2021; ECDC, 2021).

Pandemia de COVID-19 a dus la creșterea marcată și rapidă a cererii de servicii medicale, inclusiv de urgență și terapie intensivă, punând la încercare sistemele de sănătate publică din fiecare țară, care s-au confruntat în același timp și cu o serie de probleme etice. Una dintre provocările cu care s-au confruntat sistemele medicale în cursul pandemiei de COVID-19 a fost alocarea resurselor, în sensul prioritizării acestora în cel mai eficient mod atunci când acestea devin insuficiente. Prioritizarea ar trebui să fie cât mai obiectivă posibil, astfel încât luarea unei decizii bazate pe vârsta cronologică nu este justificată. Exista numeroase opinii conform cărora vârsta avansată nu ar trebui să fie un criteriu pentru excluderea pacienților din unitățile spitalicești specializate (Bonanad et al., 2020; EUGMS, 2021; Martínez-Sellés et al., 2020).

Studiul de față a avut drept scop evidențierea unor aspecte etice în managementul COVID-19 la pacientul vârstnic. Obiectivul studiului a fost identificarea unor aspecte medicale practice la bolnavii spitalizați pentru infecția cu SARS-CoV-2 prin analiza unor caracteristici epidemiologice și clinico-evolutive ale acestora. 


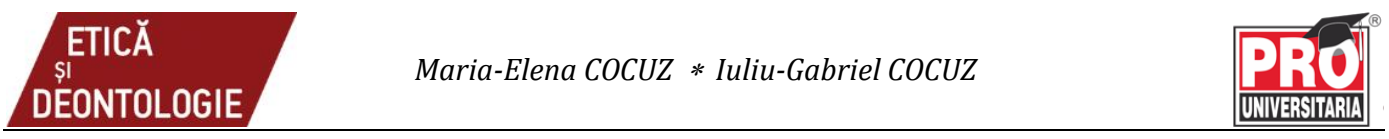

\section{Material și metodă}

Am efectuat un studiu retrospectiv, observațional și descriptiv, asupra cazurilor de COVID-19 - pacienți vârstnici internați în Spitalul Clinic de Boli Infecțioase din Brașov în perioada 01.03.2021-31.03.2021. Studiul a fost realizat în baza consimțământului scris al pacienților pentru participarea la activități didactice si de cercetare și a fost avizat de Comisia pentru Studii Clinice din cadrul spitalului.

\section{Rezultate și discuții}

În perioada 01.03.2021-31.03.2021 în Spitalul Clinic de Boli Infecțioase din Brașov au fost internați 202 pacienți cu COVID-19, dintre care 51,48\% au fost persoane cu vârsta de peste 65 de ani. Constatăm astfel proporția crescuta de bolnavi vârstnici care au necesitat spitalizare și tratament.

Analiza pe grupe de vârstă a evidențiat faptul că au fost internați pacienți cu vârste variate. Cea mai mare proporție s-a înregistrat pentru intervalul de 65-74 de ani - 69,23\% cazuri, un sfert dintre pacienți au avut vârsta de 75-84 de ani si doar un număr redus de bolnavi a depășit 85 de ani. Cel mai înaintat în etate pacient a avut vârsta de 95 de ani (fig.1):

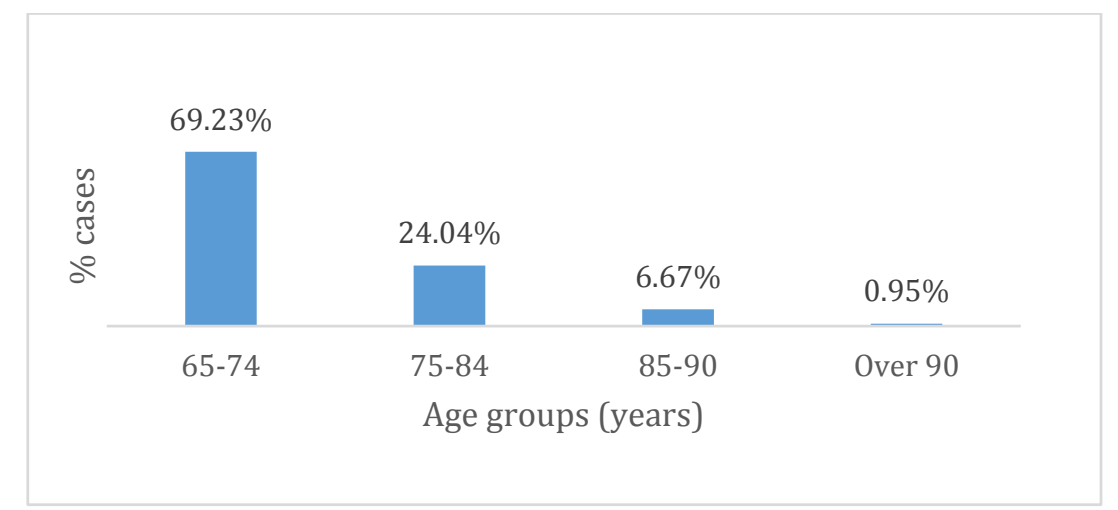

Fig. 1. Frecvența internărilor pentru COVID-19 în raport cu grupele de vârstă (Sursa: Spitalul Clinic de Boli Infecțioase din Brașov, 01.03.2021-31.03.2021)

Gravitatea bolii a fost evaluată prin încadrarea în variate forme clinice de boală. De asemenea a fost analizată frecvența prezenței insuficienței respiratorii acute, situație ce impune administrarea de oxigen suplimentar. S-a constatat faptul că au predominat formele medii și medio-severe, în proporții apropiate, de $43,27 \%$ și respectiv $42,31 \%$ cazuri. Formă severă au prezentat $14,42 \%$ dintre bolnavi. Niciun pacient nu a prezentat o evoluție ușoară (fig.2): 


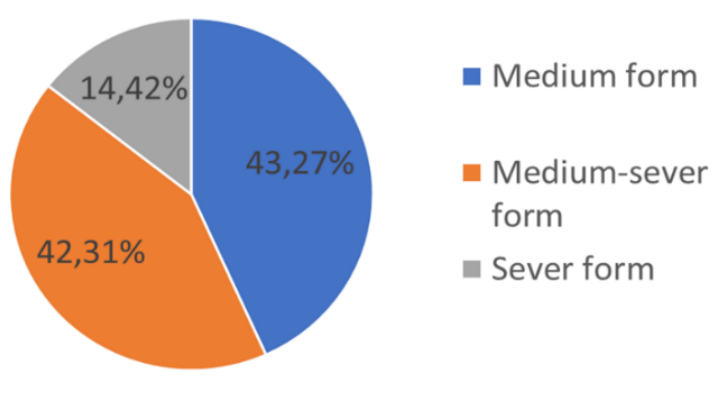

Fig. 2. Forme clinice de COVID-19 la pacienții vârstnici

(Sursa: Spitalul Clinic de Boli Infecțioase din Brașov, 01.03.2021-31.03.2021)

Insuficiența respiratorie acută a fost identificată in tabloul clinic al bolii la o proporție importantă dintre pacienți - 87,50\% de cazuri (fig.6).

A fost analizată severitatea formei clinice de boală raportat la grupele de vârsta. S-a constatat faptul că la grupa de vârsta 65-74 de ani au fost prezente în proporții egale formele medii și medio-severe de boală. Forma severă a fost foarte rară. La grupa de vârsta 75-84 de ani forma medio-severă a fost diagnosticată la jumătate dintre pacienți, forma medie scade ca frecvență iar forma severă a fost evidențiată la $16,66 \%$ dintre bolnavi. La bolnavii cu vârsta de peste 84 de ani proporția formelor medio-severe crește iar evoluția severă se menține la valori relativ constante (fig.3):

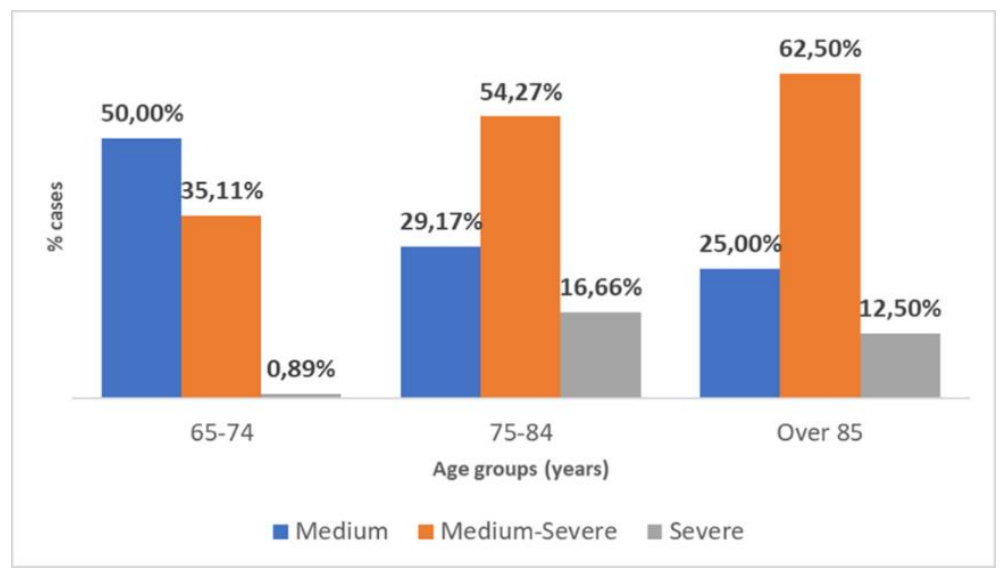

Fig. 3. Forme clinice de COVID-19 la vârstnici în raport cu grupele de vârstă (Sursa: Spitalul Clinic de Boli Infecțioase din Brașov, 01.03.2021-31.03.2021)

Se poate observa că frecvența formelor medio-severe și severe de boală crește proporțional cu vârsta.

Coroborând datele mai sus prezentate se constată faptul că aproape o treime dintre pacienții vârstnici internați cu COVID-19 au avut vârstă înaintată, cu forme 
STICA
ȘIONTOLOGIE grave de boală, insuficiență respiratorie asociată, elemente ce au crescut riscul de deces și au determinat necesitatea aplicării unor măsuri complexe de tratament și îngrijire medicală permanentă,

Am analizat asocierea de comorbidități la pacienții vârstnici cu COVID-19. Am identificat o serie de afecțiuni cronice, prezente în diferite proporții: boli cardiovasculare - 79,80\% cazuri, diabet zaharat - 35,35\% bolnavi, boală renală cronică $24,24 \%$ cazuri, afecțiuni hematologice si oncologice în proporții egale cu boli neurologice - 19,19\% cazuri, boli respiratorii cronice - 15,15\%. Obezitate au prezentat $10,10 \%$ dintre bolnavi (fig. 4):

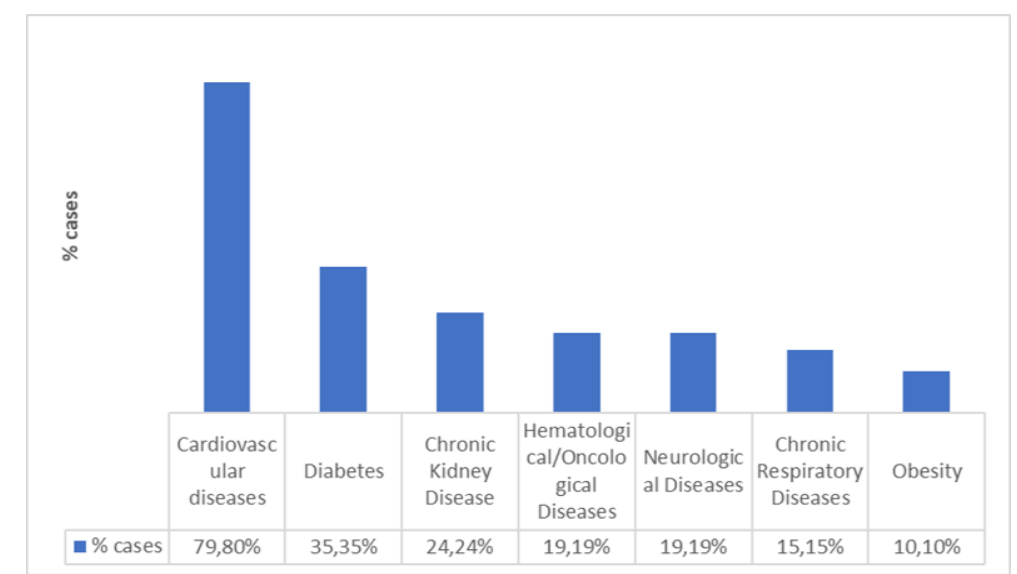

Fig. 4. Boli cronice asociate la pacienții vârstnici internați cu COVID-19 (Sursa: Spitalul Clinic de Boli Infecțioase din Brașov, 01.03.2021-31.03.2021)

Tipurile de afecțiuni cronice identificate la pacienții vârstnici internați cu COVID-19 au fost singulare in 28,85\% din cazuri și asociate câte 2, 3 sau chiar 4 la același pacient (fig.5):

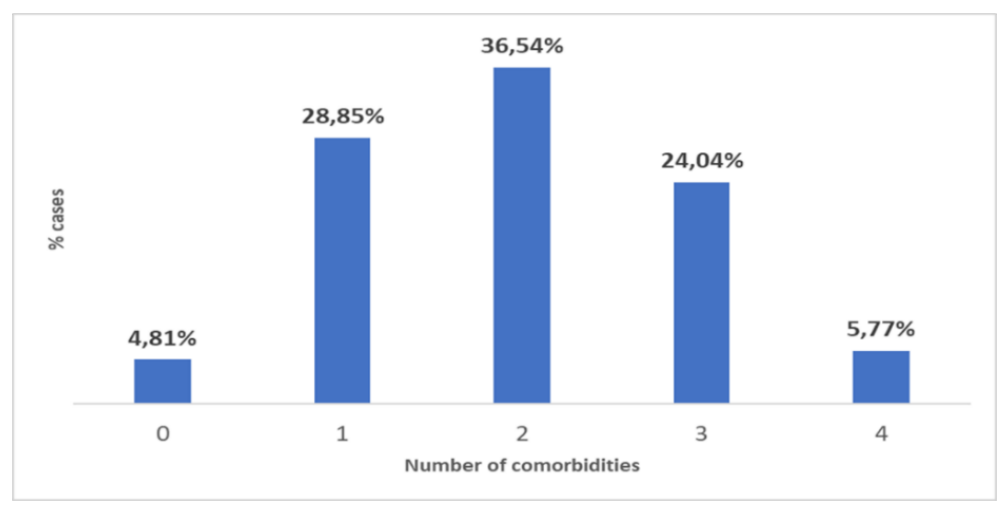

Fig .5. Grupe de comorbidități la pacienții vârstnici internați cu COVID-19

(Sursa: Spitalul Clinic de Boli Infecțioase din Brașov, 01.03.2021-31.03.2021) 
Evoluția COVID-19 la pacienții vârstnici din lotul de studiu a fost favorabilă în $84,54 \%$ din cazuri, cu externare din spital. Transferul în secții ATI a fost necesar la 7,69\% dintre bolnavi, datorită agravării evoluției bolii și necesității aplicării unor măsuri suplimentare de tratament. De asemenea s-au efectuat transferuri și în alte secții de spital în 1,92\% din cazuri pentru continuarea tratamentelor și monitorizării pentru afecțiunile asociate. Decese s-au înregistrat la 3,85\% dintre bolnavi (fig. 6):

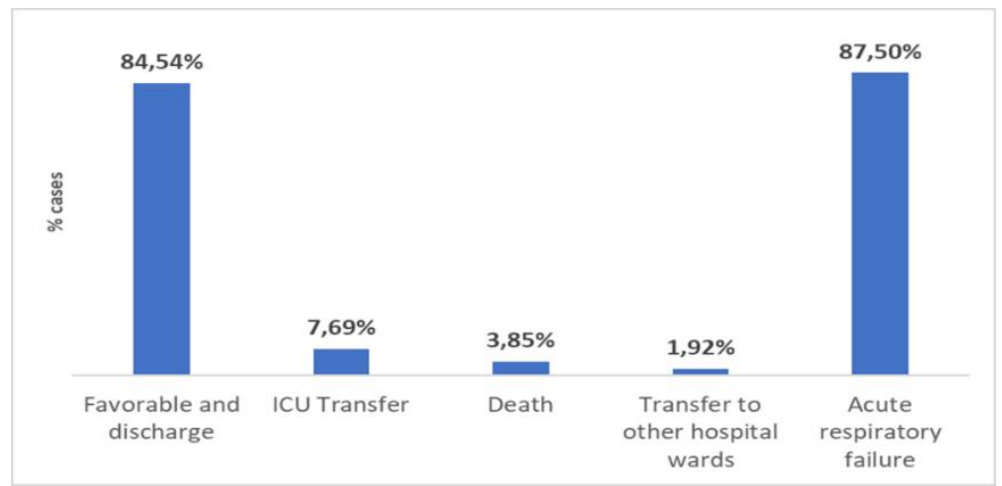

Fig. 6. Evoluția pacienților vârstnici internați cu COVID-19 (Sursa: Spitalul Clinic de Boli Infecțioase din Brașov, 01.03.2021-31.03.2021)

Analiza cazurilor în complexitatea dată de necesitatea evaluării mai multor elemente legate de pacientul vârstnic și de îngrijirea medicală a acestuia a dus la conturarea unor aspecte practice în managementul pacientului vârstnic cu COVID-19.

Pe prim plan s-a situat alegerea, aplicarea și monitorizarea tratamentului pentru COVID-19. S-au luat în considerare forma clinică de boală și schema de tratament adecvată acesteia, posibilele interacțiuni între medicamentele din prescripția pentru COVID-19 și cele de fond pentru bolile cronice asociate, posibilele efecte adverse ale medicației pentru afecțiunea virală în contextul atenționărilor legate de vârsta pacienților și de comorbiditățile acestora. 0 problemă deosebită a fost reprezentată de decizia argumentată de administrare a oxigenului suplimentar în prezența insuficienței respiratorii acute și de aplicare a acestei terapii în condiții de siguranță pentru pacienți și pentru personalul medical.

Un alt aspect constatat a fost necesitatea administrării simultane și monitorizării tratamentului pentru bolile cronice asociate ale pacienților. Asocierea mai multor tipuri de boli cronice la același pacient precum și marea varietate a acestora a crescut complexitatea îngrijirilor acordate pacienților. În același context sa poziționat și supravegherea evoluției în cursul spitalizării a bolilor cronice asociate și intervenția în cazul decompensării acestora. În unele situații a fost nevoie de abordare multidisciplinară pentru stabilirea terapiilor adecvate momentului. 
Infecția cu SARS-COV-2 se caracterizează prin contagiozitate înaltă și risc crescut de îmbolnăvire a persoanelor din jurul pacienților, inclusiv a personalului medical. Astfel încât izolarea pacienților în saloanele spitalului a fost riguros respectată iar vizitele din partea aparținătorilor nu au fost permise decât în cazuri excepționale. În plus, in contextul vârstei înaintate și a gravității formelor de boală, mobilitatea bolnavilor a fost mult diminuată. Toate acestea au dus la apariția și ulterior accentuarea unui sentiment de izolare, fapt ce a necesitat intervenții susținute din partea personalului medical și a psihologului.

Un alt aspect constatat a fost necesitatea de acordare de îngrijiri medicale specifice adaptate vârstnicilor, în special legate de asigurarea nevoilor fiziologice, prevenirea escarelor, prevenirea căderilor. Îngrijirea pacientului vârstnic internat în spital a necesitat cunoștințe de geriatrie și nursing geriatric și abilități de comunicare medic/asistent medical/personal de îngrijire - pacient. Toate aceste aspecte au fost marcate de acordarea acestor îngrijiri în condiții de necesitate de purtare a unui echipament de protecție complet de către personalul medical, pentru prevenirea îmbolnăvirilor.

\section{Concluzii}

Studiul unor aspecte epidemiologice și clinico-evolutive la pacienții cu vârsta de peste 65 de ani internați în Spitalul Clinic de Boli Infecțioase din Brașov în perioada 01.03.2021-31.03.2021, efectuat în scopul evidențierii unor aspecte etice în managementul COVID-19 la pacientul vârstnic, a permis stabilirea următoarelor concluzii:

1. Internările pentru COVID-19 la persoanele vârstnice au fost numeroase, bolnavii asociind multiple, variate și severe comorbidități.

2. Formele clinice de COVID-19 la vârstnici au fost grave într-o proporție crescută de cazuri, cu insuficiență respiratorie acută, necesitând abordare terapeutică complexă, cu evoluție favorabilă în majoritatea cazurilor.

3. Managementul adecvat al COVID-19 la vârstnic necesită intervenții medicale multidisciplinare, simultane, adaptate particularităților bolii, afecțiunilor cronice asociate și vârstei.

4. Aplicarea terapiei specifice și a îngrijirilor medicale adecvate și complete pentru COVID-19 trebuie să fie nediscriminatorie, indiferent de vârsta pacientului iar în caz de resurse limitate prioritizarea utilizării acestora necesită o evaluare corectă a fiecărui caz în parte. 


\section{Referințe}

Bonanad C, García-Blas S, José Tarazona-Santabalbina F, et al., (2020), Coronavirus: the geriatric emergency of 2020. Joint document of the Section on Geriatric Cardiology of the Spanish Society of Cardiology and the Spanish Society of Geriatrics and Gerontology. Rev Esp Cardiol. 2020 Jul;73(7):569-576. doi: 10.1016/j.recesp.2020.03.027. Epub 2020 Apr 3

Britannica, (2021), COVID-19 in 20 Questions, https://www.britannica.com/list/covid-19-in-20questions, accesat la 10 iulie 2021.

Cennimo D., Coronavirus Disease 2019 (COVID-19), https://emedicine.medscape.com/article/ 2500114-overview, accesat la 11 iulie 2021.

ECDC, (2021), European Centre for Disease Prevention and Control. High-risk groups for COVID-19, https://www.ecdc.europa.eu/en/covid-19/high-risk-groups, accesat la 10 iulie 2021.

EUGMS, (2021), European Geriatric Medicine. Statement of the EuGMS Executive Board on the COVID-19 epidemic, https://www.eugms.org/news/read/article/489.html, accesat la 13 iulie 2021.

Guan WJ, Ni ZY, Hu Y, et al., (2020), Clinical Characteristics of Coronavirus Disease 2019 in China, N Engl J Med, 2020 Apr 30; 382(18):1708-1720. doi: 10.1056/NEJMoa2002032.

INS, (2021a), Centrul Național de Supraveghere și Control al Bolilor Transmisibile. Situație infecții coronavirus (Covid 19) 1207 2021, http://www.cnscbt.ro/index.php/situatia-la-nivelglobal-actualizata-zilnic, accesat la 12 iulie 2021.

INS, (2021b), Centrul Național de Supraveghere și Control al Bolilor Transmisibile. Analiză cazuri confirmate COVID 19, http://www.cnscbt.ro/index.php/analiza-cazuri-confirmatecovid19, accesat la 12 iulie 2021.

Interim Clinical Guidance, (2021), Interim Clinical Guidance for Management of Patients with Confirmed Coronavirus Disease (COVID-19), https://www.cdc.gov/coronavirus/2019ncov/hcp/clinical-guidance-management-patients.html, accesat la 10 iulie 2021.

Martínez-Sellés D, Martínez-Sellés H, Martinez-Sellés M., (2020), Ethical Issues in Decision-making Regarding the Elderly Affected by Coronavirus Disease 2019: An Expert Opinion. European Cardiology Review 2020;15:e48. DOI:https://doi.org/10.15420/ecr.2020.14.

Onder G, Rezza G, Brusaferro S., (2020), Case-fatality rate and characteristics of patients dying in relation to COVID-19 in Italy. JAMA. 2020. doi:10.1001/jama.2020.4683.

Q\&A COVID-19, (2021), Questions and answers on COVID-19: Basic facts, https://www.ecdc.europa. eu/en/covid-19/questions-answers/questions-answers-basic-facts, accesat la 10 iulie 2021.

WHO, (2020a), WHO Director-General's opening remarks at the media briefing on COVID-19 11.March.2020, https://www.who.int/director-general/speeches/detail/who-directorgeneral-s-opening-remarks-at-the-media-briefing-on-covid-19---11-march-2020, accesat la 13 iulie 2021.

WHO, (2020b), World Health Organization. Naming the coronavirus disease (COVID-19) and the virus that causes it; 2020, https://www.who.int/emergencies/diseases/novelcoronavirus-2019/technical-guidance/naming-the-coronavirus-disease-(covid-2019)and-the-virus-that-causes-it, accesat la 10 iulie 2021

WHO, (2020c), World Health Organization. WHO director-general's opening remarks at the media briefing on COVID-19-11 March 2020, https://www.who.int/director-general/speeches/ detail/who-director-general-s-opening-remarks-at-the-media-briefing-on-covid-19--11-march-2020, accesat la 10 iulie 2021. 